\title{
The Role of Dietary Protein and Fat in Glycaemic Control in Type 1 Diabetes: Implications for Intensive Diabetes Management
}

\author{
Megan Paterson ${ }^{1,2} \cdot$ Kirstine J. Bell ${ }^{2} \cdot$ Susan M. O'Connell ${ }^{3}$ - Carmel E. Smart ${ }^{1,2}$. \\ Amir Shafat ${ }^{4}$ Bruce King ${ }^{1,2}$
}

Published online: 23 July 2015

(C) The Author(s) 2015. This article is published with open access at Springerlink.com

\begin{abstract}
A primary focus of the management of type 1 diabetes has been on matching prandial insulin therapy with carbohydrate amount consumed. However, even with the introduction of more flexible intensive insulin regimes, people with type 1 diabetes still struggle to achieve optimal glycaemic control. More recently, dietary fat and protein have been recognised as having a significant impact on postprandial blood glucose levels. Fat and protein independently increase the postprandial glucose excursions and together their effect is additive. This article reviews how the fat and protein in a meal impact the postprandial glycaemic response and discusses practical approaches to managing this in clinical practice. These insights have significant implications for patient education, mealtime insulin dose calculations and dosing strategies.
\end{abstract}

Keywords Type 1 diabetes $\cdot$ Fat $\cdot$ Protein $\cdot$ Carbohydrate . Glycaemia $\cdot$ Insulin

This article is part of the Topical Collection on Lifestyle Management to Reduce Diabetes/Cardiovascular Risk

Bruce King

Bruce.King@hnehealth.nsw.gov.au

Megan Paterson

Megan.Paterson@hnehealth.nsw.gov.au

Kirstine J. Bell

Kirstine.Bell@newcastle.edu.au

Susan M. O'Connell

Soconnel15@hotmail.com

Carmel E. Smart

Carmel.Smart@hnehealth.nsw.gov.au

\section{Introduction}

Intensive insulin management and good glycaemic control are essential for the prevention of acute and long-term diabetes complications and the overall wellbeing in people with type 1 diabetes [1,2]. Multiple daily injection (MDI) therapy involves injecting long-acting insulin once or twice daily (basal) and injections of rapid-acting insulin before each meal. This remains the most common form of insulin therapy for type 1 diabetes; however, insulin pump therapy (IPT) is becoming an increasingly popular form of therapy. An extension of MDI and IPT is flexible intensive insulin therapy, which involves calculating the mealtime insulin based on carbohydrate $(\mathrm{CHO})$ content of the meal and the pre-prandial blood glucose level (BGL) [1, 3, 4]. Adjusting insulin doses based on $\mathrm{CHO}$ intake in intensive insulin regimes has been shown to improve glycaemic control, decrease hypoglycaemia and improve quality of life [1, 3-8]. However, even with the intro-
Amir Shafat

Amir.Shafat@nuigalway.ie

1

Department of Paediatric Diabetes and Endocrinology, John Hunter Children's Hospital, Newcastle, NSW, Australia

2 Hunter Medical Research Institute, School of Medicine and Public Health, University of Newcastle, Rankin Park, NSW, Australia

3 Department of Paediatrics and Child Health, Cork University Hospital, Cork, Ireland

4 Physiology, School of Medicine, National University of Ireland, Galway, Galway, Ireland 
duction of intensive insulin regimes, analogue insulins and CHO quantification, day-to-day glucose variability remains a major issue [9] and diabetes centres have not seen the anticipated improvements in glycaemic control [10-12]\}.

One of the key factors affecting the mean BGL and HbAlc is the postprandial BGL. Postprandial BGLs have been shown to increase the risk factors for cardiovascular disease in people with type 1 diabetes $[13,14]$. Hence, factors that increase the postprandial BGL have the potential to increase $\mathrm{HbAlc}$ and the risk of complications.

Although $\mathrm{CHO}$ is the predominant macronutrient affecting postprandial BGL, recent research has shown that dietary fat and protein can also significantly impact the postprandial glycaemic profile (Fig. 1) [16, 17, 18・•, 19・•], and thus adjusting the prandial insulin dose for these macronutrients may be beneficial $[16,20 \bullet \cdot$.

Dietary CHO is digested into glucose (and other monosaccharides) and transported into the bloodstream, where it directly raises the blood glucose concentration. Since other macronutrients, including protein and fat, have little direct impact on postprandial glycaemia in healthy subjects, they were essentially ignored for determining prandial insulin doses. Early research in the 1980s confirmed this relationship between $\mathrm{CHO}$ and insulin therapy in type 1 diabetes using an artificial pancreas [21-23]. Around the same time, there was evidence to suggest that high-fat and high-protein meals influence exogenous insulin requirements in type 1 diabetes, however these were largely overlooked in the enthusiasm for carbohydrate counting $([24,25]$.

Optimising insulin dosing for fat and protein is an important clinical issue given fat and protein are recommended to comprise a combined $45-50 \%$ of daily energy intake ( $30 \%$ for fat and 15-20\% for protein) [26, 27]. Furthermore, low$\mathrm{CHO}$ diets (with consequently higher intakes of fat and protein) have recently received a great deal of media attention and are becoming increasingly popular.

This article will therefore review the evidence regarding the glycaemic impact of fat and protein and discuss the clinical implications and mealtime insulin dosing strategies in the management of type 1 diabetes.

\section{Fat}

\section{Glycaemic Impact}

Unlike proteins or $\mathrm{CHO}$, fat is rarely consumed in isolation as a single macronutrient, therefore the impact of fat is usually considered in terms of its ability to modify the CHO-induced blood glucose response.

In healthy people and people with type 1 diabetes, adding fat to a $\mathrm{CHO}$ meal reduces the glycaemic response in the early postprandial period (first $1-3 \mathrm{~h}$ ) but
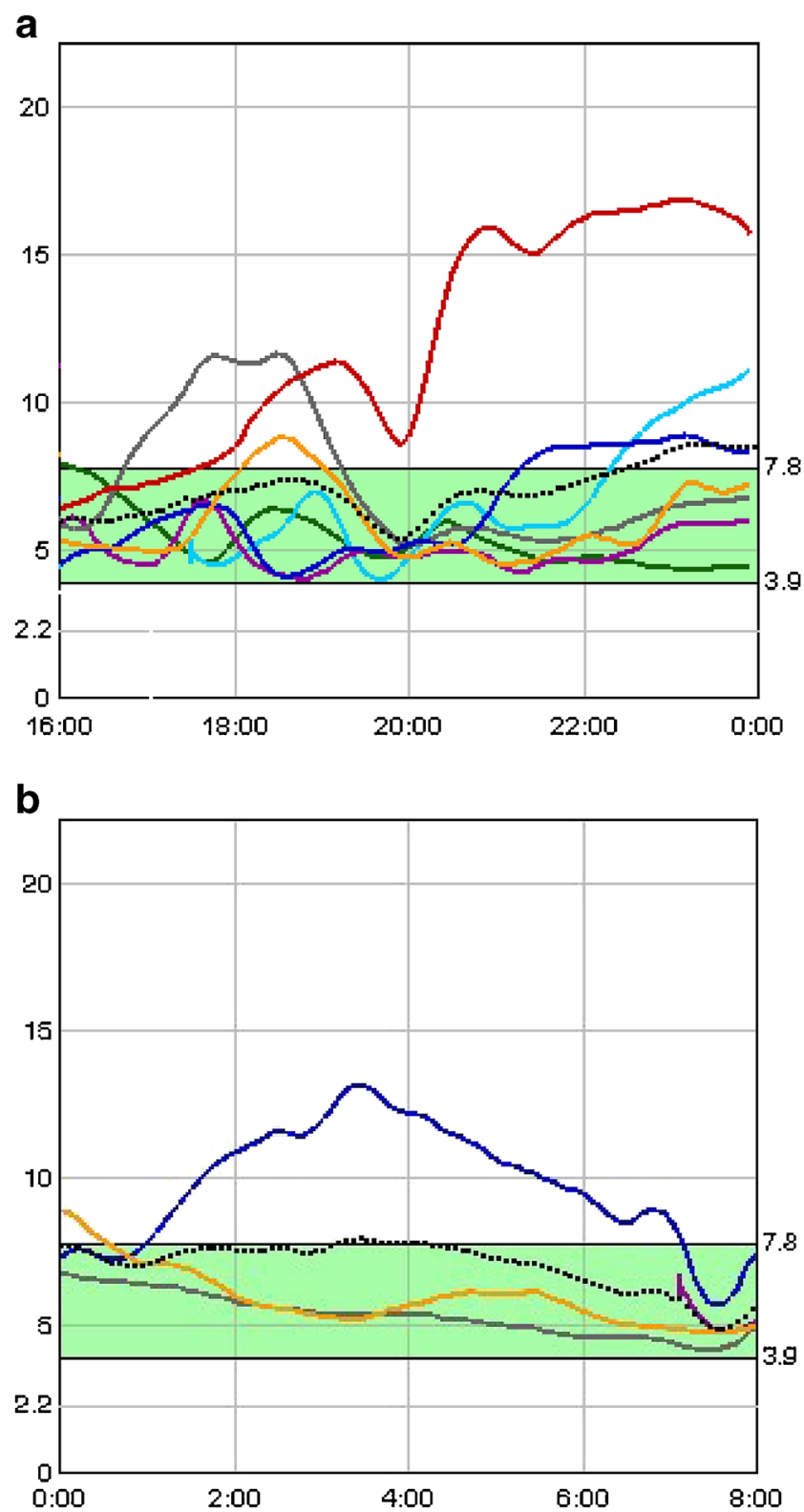

Fig. 1 Continuous glucose sensor results demonstrating the impact of macronutrients on postprandial glycaemia. Graph A is a 10 -year-old female with type 1 diabetes on insulin pump therapy who was well controlled but ate pizza at 18:00 (red line). The standard bolus did cover the first $2 \mathrm{~h}$ but then she developed extended hyperglycaemia. Graph B is an 18-year-old male with type 1 diabetes on insulin pump therapy who ate fried chicken at 22:00 (blue line). The standard bolus controlled the initial postprandial period but he developed hyperglycaemia $3 \mathrm{~h}$ later which lasted $6 \mathrm{~h}$. (With permission from: Smart, C. Diabetes Care for Children and Young People. Diabetes and Primary Care 2013, 2(2):71-73) [15]

extends the glycaemic response over hours. Using continuous glucose monitoring (CGM) profiles in 24 healthy non-diabetic adults, Freckmann et al. demonstrated that meals with a higher fat content induced a smaller increase and a slower decrease of postprandial 
glucose concentrations than a high-carbohydrate low-fat meal [28].

As with healthy individuals, the addition of fat tends to decrease the glycaemic response in the early postprandial period in people with type 1 diabetes, and thus increases the risk of hypoglycaemia. However, in the late postprandial period, high-fat meals often cause significant hyperglycaemia lasting for several hours following the meal. This hyperglycaemia is problematic for good glycaemic control, particularly since high-fat meals are often consumed for the evening meal when prolonged hyperglycaemia may not be detected until the following morning. A recent study of the dietary factors associated with nocturnal hypoglycaemia in adults has shown a significant association with post-dinner fat intake and higher rates of nocturnal hyperglycaemia occurrence [29].

Several studies looking at the effects of dietary fat have been published in recent years. We have shown that the addition of $35 \mathrm{~g}$ of dietary fat to $30 \mathrm{~g}$ of CHO initially reduces the glycaemic excursion for up to 90 min following the meal but then significantly increases the postprandial glycaemic response from $3 \mathrm{~h}$ onwards, with the BGL increased by $2.3 \mathrm{mmol} / \mathrm{L}$ at $5 \mathrm{~h} \mathrm{[18 \bullet \bullet ].} \mathrm{In} \mathrm{an} \mathrm{insulin} \mathrm{clamp} \mathrm{study,} \mathrm{Wolpert}$ et al. also demonstrated that a high-fat meal (50 $\mathrm{g}$ of fat) causes significant hyperglycaemia over $5 \mathrm{~h}$, even with additional insulin infused [19••].

\section{Mechanisms of Action}

Unlike proteins or $\mathrm{CHO}$, fat is rarely consumed on its own as a single macronutrient. Triacylglycerols (TAGs) constitute more than $90 \%$ of lipids in the human diet, and this review will focus on their role in the management of BGLs.

TAGs can influence the glycaemic response in type 1 diabetes by (1) gluconeogenesis of glycerol, (2) a direct effect of free fatty acids (FFA), (3) effects on other hormones and (4) effects on gastric emptying.

\section{Gluconeogenesis from fat}

Dietary fat is not converted to glucose in any substantial amounts. Fatty acids are metabolised to ketones which cannot be used in gluconeogenesis [30]. In contrast, glycerol from the hydrolysis of TAGs can be metabolised to pyruvate and synthesised into glucose [30]. However, glycerol only makes up 5-15\% of the weight of TAGs (depending on which fatty acids are in the TAG) and only part of the glycerol would be converted to glucose with the rest entering the glycolytic pathway [31].

2. Direct effect of fatty acids

Circulating FFAs have a direct effect on the beta cells causing increased glucose-stimulated insulin secretion, which has been attributed to interactions with a $G$ protein-coupled receptor [31]. Additionally, FFAs are the ligand for peroxisome proliferator-activated receptors
(PPARs). The thiazolidinediones are PPAR $\gamma$ agonists which are used in the management of type 2 diabetes. See Grygiel-Gorniak for a review of PPARs [32].

3. Effects of fats on other hormones

Dietary fat has been shown to alter the release of other hormones which impact on glycaemic regulation including glucagon, glucagon-like protein 1 (GLP-1), gastric inhibitor polypeptide (GIP) and ghrelin.

In healthy subjects, when fat is consumed alone, postprandial glucagon and GLP-1 levels increase, but if the fat is consumed with $\mathrm{CHO}$, the glucagon and GLP-1 levels do not increase [33]. Ladbroke et al. found that when adolescents with type 1 diabetes consumed a high-fat and high-CHO meal, GLP-1, GIP and ghrelin increased [34]. The impact of dietary fat on other hormones is beyond the scope of this article, and the reader is referred to other reviews [35].

\section{Effect of fat on gastric emptying}

The duodenal delivery of nutrients is a major determinant of BGL. As the $\mathrm{CHO}$ absorption capacity of the small intestine far exceeds the duodenal delivery, gastric emptying is a rate-limiting step in glucose absorption [36, 37]. As the stomach empties at a constant energy rate $(8.4 \mathrm{~kJ} / \mathrm{min})$, addition of fat to a meal will delay the rate of gastric emptying of $\mathrm{CHO}$ [38]. Addition of fat to a $\mathrm{CHO}$ meal delayed and reduced the glycaemic and insulinemic responses in healthy individuals [39]. Clegg et al. showed that in healthy subjects, the chain length and saturation of fat is important and changes the glycaemic response to a meal [40].

The impact of dietary fat on gastric emptying of the subsequent meal regardless of its content also needs consideration, as dietary fat from breakfast has been shown to delay the rate of gastric emptying of the subsequent lunch meal [41]. Furthermore, intake of high-fat diet for 1 week desensitises gastrointestinal transit and leads to a more rapid gastric emptying [42].

Because of fats impact on gastric emptying, modification of dietary fat content is used in the management of diabetesrelated gastroparesis.

\section{Protein}

\section{Glycaemic Impact}

In individuals without diabetes, dietary protein does not alter postprandial glycaemia [43], however, it stimulates a significant postprandial insulin response, which is required for amino acid uptake [44]. In order to maintain euglycaemia, protein concurrently stimulates glucagon secretion, thereby promoting hepatic glucose release and regulation of BGL [45-47]. 
In contrast, when people with type 1 diabetes consume protein, there is an increase in postprandial BGLs and insulin requirements. Studies comparing the postprandial glycaemic responses to standard meals with meals containing between 28 and $57 \mathrm{~g}$ of additional protein have demonstrated significantly higher postprandial glycaemic excursions and insulin requirements in the $2-5 \mathrm{~h}$ postprandial period in type 1 diabetes [17, $18 \bullet \bullet, 45,48]$. More recently, our group looked at the glycaemic impact of ingested protein only (independent of $\mathrm{CHO}$ and fat) in children and young adults with type 1 diabetes [49]. Consumption of $\geq 75 \mathrm{~g}$ of protein resulted in a significantly delayed, sustained, elevated, postprandial glycaemic excursion from 180 to 300 min compared with a control drink (water). The peak BGL from $\geq 75 \mathrm{~g}$ of protein was similar to that of $20 \mathrm{~g}$ of glucose given without insulin; however, the shape of the glycaemic response was significantly different. Following the ingestion of protein, the BGL only began to rise after $100 \mathrm{~min}$ and reached the peak BGL after $5 \mathrm{~h}$.

These findings demonstrate that for people with type 1 diabetes the addition of $\geq 28 \mathrm{~g}$ of protein to a mixed meal or consuming $\geq 75 \mathrm{~g}$ of protein alone is likely to result in significant and sustained postprandial hyperglycaemia commencing in the late postprandial period (2-3 h) and continuing beyond $5 \mathrm{~h}$. Clinically, this is important when determining whether additional insulin is required and, importantly, how to safely calculate and distribute these increased doses.

The sustained postprandial hyperglycaemic effect of protein could potentially be utilised to decrease nocturnal hypoglycaemia, however, research has shown that high-fat meals (which also have sustained postprandial hyperglycaemia) did not prevent nocturnal hypoglycaemia [50]. Hence, further research is required to determine if high-protein meals would decrease nocturnal hypoglycaemia.

\section{Mechanisms of Action}

Two mechanisms have been proposed by which dietary protein may cause delayed and sustained postprandial glycaemic excursions in people with type 1 diabetes: (1) the alteration of hormones which affects glucose homeostasis and (2) the conversion of amino acids to glucose by gluconeogenic pathways.

1. Alteration of hormones which affect glucose homeostasis Ingestion of a high-protein meal has been shown to increase circulating plasma glucagon in both healthy people and people with type 1 diabetes [45-47]. In people without diabetes, the concurrent stimulation of glucagon counters the effects of protein-induced insulin release (whilst still allowing insulin to transport amino acids into the cells), and thus, there is minimal impact on postprandial glycaemia. However, in people with type 1 diabetes, this increase in plasma glucagon in the absence of sufficient insulin has been shown to cause postprandial hyperglycaemia $[45,51]$.

Meal protein content also influences a number of other hormones, such as cortisol, growth hormone, IGF-1 and ghrelin, but how these hormonal changes subsequently influence postprandial glucose levels is poorly understood. High-protein meals produce increased cortisol concentrations [52], which in turn may increase insulin resistance and insulin requirements. Meals that are high protein and low $\mathrm{CHO}$ produce increased growth hormone levels; however, when the meal contains significant amounts of $\mathrm{CHO}$, growth hormone is unchanged or decreased [53]. Meals high in protein increase circulating IGF-1 levels and decrease ghrelin levels [54].

2. Conversion of amino acids to glucose (gluconeogenesis)

Amino acids can act as an energy source by being converted to glucose (glucogenic amino acids) or into ketone bodies (ketogenic amino acids). There are 20 amino acids that are encoded by the nuclear genes of eukaryotes, 13 are exclusively glucogenic, 2 are exclusively ketogenic and 5 are glucogenic and ketogenic. Hence, 18 out of the 20 amino acids (90\%) can be converted to glucose. The exclusively glucogenic amino acids are glycine, serine, valine, histidine, arginine, cysteine, proline, alanine, glutamate, glutamine, aspartate, asparagine and methionine. The amino acids that are both glucogenic and ketogenic are isoleucine, threonine, phenylalanine, tyrosine and tryptophan. The exclusively ketogenic amino acids are leucine and lysine [55]. When circulating insulin levels are inadequate, there is an uptake of glucogenic amino acids by the liver, thereby increasing gluconeogenesis and resulting in increased plasma BGL [56-58].

A study by Khan et al. showed that $50 \mathrm{~g}$ of ingested protein resulted in an additional $9.7+/-5.7 \mathrm{~g}$ of glucose in the circulation over $8 \mathrm{~h}$ in healthy adult males [43]. This demonstrates that by weight, $19.4 \%$ of the total amount of protein ingested can be converted to glucose. However, considering only the amount of glucose that enters the circulation ignores the protein-induced hormonal response (as discussed above) and that some additional insulin may be needed to counter the resulting decrease in insulin sensitivity.

Alternatively, Pańkowska et al. have proposed that $100 \mathrm{kcal}$ of fat/protein requires the equivalent amount of insulin as $10 \mathrm{~g}$ of glucose [16, 59]. Using this ratio (protein contains $4.1 \mathrm{kcal} /$ $\mathrm{g}), 100 \mathrm{kcal}$ of protein $=24.4 \mathrm{~g}$ of protein $=10 \mathrm{~g}$ of glucose. This is approximately twice the amount of glucose that Khan and colleagues found was produced from protein in healthy volunteers [43]. This apparent discrepancy may be explained because Khan et al. measured the amount of glucose produced, whereas Pańkowska et al. used clinical response (which would account for glucose production and hormonal responses). Kordonouri et al. used the Pańkowska equation in children with type 1 diabetes using IPT and found that 
although glycaemic control was improved, the risk of postprandial hypoglycaemia was increased threefold [20••]. This suggests that further research is required to determine how much additional insulin is required to cover the protein component of a meal.

\section{Combining Fat and Protein}

Although both protein and fat can independently increase postprandial glycaemia in type 1 diabetes, most meals contain both fat and protein so it is important to consider the impact of these nutrients in combination. Our research has revealed that when both fat and protein are added to a meal, their glycaemic impacts are additive. The addition of $30 \mathrm{~g}$ of fat to $30 \mathrm{~g}$ of $\mathrm{CHO}$ increased glycaemia by $1.8 \mathrm{mmol} / \mathrm{L}$ at $5 \mathrm{~h}$, and similarly, the addition of $40 \mathrm{~g}$ of protein to the same amount of $\mathrm{CHO}$ increased glycaemia by $2.4 \mathrm{mmol} / \mathrm{L}$ at $5 \mathrm{~h}$ $[18 \bullet \cdot$. However when both nutrients were added to the meal, the postprandial glycaemic response was increased by $5.4 \mathrm{mmol} / \mathrm{L}$, the sum of the effects of the two nutrients individually $[18 \bullet \bullet]$.

Our results are supported by other studies in the literature. Neu et al. showed that the addition of $82 \mathrm{~g}$ of protein and $33 \mathrm{~g}$ of fat to $70 \mathrm{~g}$ of protein increased the glucose response by $40 \%$ over $12 \mathrm{~h}$, with significant differences in glycaemia seen from 4 to $12 \mathrm{~h}$ and the peak difference observed $6 \mathrm{~h}$ following the meal [60]. Similarly, Garcia-Lopez et al. found that the glucose profile varied significantly with time when both fat and protein were added to a $\mathrm{CHO}$ meal. When the low protein/ fat meal was consumed, the peak BGL was reached after $1 \mathrm{~h}$ and returned to baseline by $3 \mathrm{~h}$. However, when fat and protein were added to the same meal, the peak BGL was delayed by $30 \mathrm{~min}$ but stayed elevated for the remainder of the $3 \mathrm{~h}$ test session and did not return to baseline [48].

\section{Dosing Insulin for Fat and Protein}

As both fat and protein increase postprandial glycaemia beyond that of $\mathrm{CHO}$ alone, effective strategies to adjust insulin doses for these macronutrients are required. It is important to note that in practice, people consume mixed meals containing combinations of $\mathrm{CHO}$, protein and fat, and therefore, the overall impact of these macronutrients on postprandial BGLs needs to be considered rather than the effect on individual nutrients. When determining how to administer insulin for meals with varying $\mathrm{CHO}$, fat and/or protein contents, it is important to consider the effects in terms of managing both the early and late postprandial glycaemic responses.

\section{Controlling the Immediate Postprandial Glycaemic Response}

Managing the early postprandial period is the first step in adjusting mealtime insulin doses, as changes implemented here will have flow-on effects for the late postprandial period.

For high CHO meals, controlling the immediate postprandial glycaemic rise is important as an increased initial glucose spike can increase the entire postprandial excursion [61]. For example, an increase in the early postprandial response by $2 \mathrm{mmol} / \mathrm{L}$, with a consequential increase in BG at all time points, could result in a $2-3 \times$ fold greater glycaemic excursion. This is especially true for meals also containing significant amounts of fat and protein, which will further increase the late postprandial period.

Changing the timing of the insulin bolus to minimise the immediate postprandial response has been investigated, however, not in the context of high-fat and/or high-protein meals. Although the immediate postprandial glucose rise is blunted after a high-fat meal, there is still a need for insulin to cover the CHO component of the meal $[18 \bullet \bullet]$. Therefore, in the author's opinion, delaying the insulin injection for high-fat meals would cause unacceptable postprandial hyperglycaemia. Research looking at the timing of the insulin bolus has shown that giving the insulin bolus before starting to eat gives superior glycaemic control compared to delaying the insulin bolus [61-63]. Conversely, for high-CHO meals also containing fat and protein, two studies have shown that dosing insulin 15 min prior to the meal was able to improve control over the initial postprandial spike, significantly reducing the peak BGL [62, 64]. However, in practice, dosing 15 min prior to a meal may prove too onerous for some patients and may result in insulin doses being forgotten. As with all diabetes management recommendations, advice should be tailored to the individual.

For patients using IPT, the insulin delivery pattern can be adjusted to better match insulin requirements. The bolus for a meal can be given as a standard bolus (where the entire dose is given within $5 \mathrm{~min}$ ), an extended bolus (where the dose is infused at a constant rate over a chosen number of hours) or a combination bolus (where a proportion of the dose is delivered immediately and the remainder is infused continuously as an extended bolus). However, not all boluses are able to control the immediate postprandial rise $[65,66]$. Chase et al. found that extended boluses did not control the immediate postprandial glucose rise with a high-fat meal [65]. Lopez et al. attempted to optimise the amplitude (height of the wave) of the extended bolus but was not able to control the immediate postprandial glucose rise compared to the standard bolus [66].

Hypoglycaemia in the early postprandial period is also a concern for low-CHO meals containing significant amounts of protein and/or fat, with patients often reporting 
hypoglycaemia soon after the meal when insulin is dosed upfront. This is likely due to mismatch between the rapid-acting insulin and the delayed gastric emptying following fat and the delayed glycaemic responses for both protein and fat. For these meals, the initial insulin dose needs to be reduced upfront but potentially increased in the latter phase, with the total dose delivered over an extended period to match the food absorption.

Changing the type of insulin delivered is an option for reducing the risk of early hypoglycaemia with MDI. To our knowledge, there are no studies comparing regular insulin with rapid-acting insulin (such as aspart or lispro insulin) for high-fat and/or high-protein meals. However, in theory, regular insulin with its slower onset of action and longer duration of action may offer an advantage in meals high in fat where gastric emptying is delayed and the initial postprandial glucose rise is blunted [18••].

\section{Controlling the Late Postprandial Glycaemic Response}

Fat and protein cause increased glycaemia continuing to 6$12 \mathrm{~h}$ after meal ingestion $[16,18 \bullet \bullet, 20 \bullet, 50]$. To cover this extended glycaemic effect of fat and/or protein, the duration of the insulin effect needs to be extended and total dose may need to be increased.

There is much debate over how additional insulin doses should be calculated and how much protein or fat needs to be consumed before insulin doses need to be adjusted. Two different algorithms have been proposed to calculate insulin for meal fat and protein content. Pankowska et al. have proposed that the insulin dose for $10 \mathrm{~g}$ of $\mathrm{CHO}$ should be equivalent to the insulin needed for every $100 \mathrm{kcal}$ of fat/protein. Alternatively, Brand-Miller et al. have proposed a food insulin index, which is a measure of the postprandial insulin response to foods in healthy subjects, as a basis for determining mealtime insulin doses in type 1 diabetes [12, 67, 68]. However, both of these methods have resulted in significant postprandial hypoglycaemia and require further research.

Closed-loop studies have suggested that for high-fat and/or high-protein meals, the insulin dose needs to be increased by $42 \%$ to as much as $125 \%$. Wolpert et al. revealed a mean insulin dose increase of $42 \%$ was needed for a high-fat meal (60 $\mathrm{g}$ fat) compared to the low-fat meal (10 $\mathrm{g}$ fat), however, given patients still experienced significantly hyperglycaemia following the high-fat meal, this dose is likely to be an underestimation [19••]. Importantly, there was a wide variation in the dose adjustment needed to cover the high-fat meal (range -17 to $+108 \%$ ), highlighting the importance of individualised advice. A subsequent study by this group used predictive modelling to optimise the insulin dose in patients using insulin pump therapy for the addition of $35 \mathrm{~g}$ of fat and $32 \mathrm{~g}$ of protein to a meal, finding a mean insulin dose increase of $78 \%$, using a combination-wave with $30 / 70 \%$ split over $2.4 \mathrm{~h}$ [69].
Similarly, there was a wide variation in the total dose increase $(+38$ to $+125 \%)$ and the optimal split and duration (range 20/ $80 \%$ to $50 / 50 \%$ and $2-3 \mathrm{~h}$ ).

Since rapid-acting insulin given as a standard bolus will not last long enough to cover the long tail caused by protein and fat, altering the insulin delivery pattern (i.e., bolus type) may assist with controlling late postprandial hyperglycaemia in patients using IPT. Extended boluses are also ineffective for high-protein/fat meals, as they are unable to control the immediate postprandial BGL rise $[65,66,70]$, even though the rate of the rise is blunted [18••]. Currently, the most effective form of insulin pump bolus for meals containing protein and/ or fat is the combination-wave bolus $[65,70,71]$. Jones et al. demonstrated that compared with a standard bolus, a combination-wave bolus significantly reduced the mean BGL and improved the amount of time spent within the normal BGL range for a high-fat pizza meal [71]. Similarly, Chase et al. also found that the combination-wave gave the best postprandial glycaemic control following a high-fat pizza and tiramisu meal [65]. To date, there are no studies looking at the optimal split of insulin between the immediate and extended bolus components for combination-wave boluses. However, studies have used $50 \%$ of insulin given immediately and $50 \%$ given as the extended bolus, and this can be used as an appropriate starting point in practice and adjusted as needed. The duration has been found to have an improved glycaemic profile when the duration of the bolus is increased from between 4 and $8 \mathrm{~h}$ [5].

Extending the insulin action time is more problematic for patients using MDI. Theoretically, the insulin injection could be given as a split bolus with two separate injections: one injection prior to the meal and the other given $1 \mathrm{~h}$ following the meal. However, this method needs to be investigated to determine its efficacy in practice.

For small meals and snacks, large adjustments of insulin doses may not be required. Wilson et al. compared a low-fat (30 g CHO, $2.5 \mathrm{~g}$ protein, $1.3 \mathrm{~g}$ fat; $138 \mathrm{kcal}$ ) and a high-fat (30 g CHO, 2 g protein, $20 \mathrm{~g}$ fat; $320 \mathrm{kcal}$ ) snack at bedtime and showed that during an 8 -h overnight period, the average BGL following the low-fat snack was 8.7 and $9.5 \mathrm{mmol} / \mathrm{L}$ following the high-fat snack [50]. In this scenario with a high-fat snack (rather than a large meal), a standard bolus for the $\mathrm{CHO}$ component and a temporary $10 \%$ increase in basal overnight would appear appropriate.

\section{Conclusion}

Although $\mathrm{CHO}$ is the principal factor influencing glycaemic response to a meal, dietary fat and protein have a major impact on postprandial glycaemia in people with type 1 diabetes, from 2 to $8 \mathrm{~h}$ after ingestion. Insulin strategies to control the glycaemic impact of high-fat and high-protein meals require 
further investigation, but the literature suggests increasing the insulin dose and delivering the insulin using a combinationwave over at least $2 \mathrm{~h}$ improves the post prandial glycaemic control. Further research is required to produce a pragmatic approach to dietary fat and protein that can be utilised in clinical practice.

Acknowledgments The authors wish to thank Stephen McInally and the Hunter Medical Research Institute for their assistance.

\section{Compliance with Ethics Guidelines}

Conflict of Interest Megan Paterson, Kirstine J. Bell, Susan M. O'Connell, Carmel E. Smart, Amir Shafat and Bruce King declare that they have no conflict of interest.

Human and Animal Rights and Informed Consent This article references human studies that have been approved by the appropriate institutional and/or national research ethics committee and have been performed in accordance with the ethical standards as laid down in the 1964 Declaration of Helsinki and its later amendments or comparable ethical standards.

Open Access This article is distributed under the terms of the Creative Commons Attribution 4.0 International License (http:// creativecommons.org/licenses/by/4.0/), which permits unrestricted use, distribution, and reproduction in any medium, provided you give appropriate credit to the original author(s) and the source, provide a link to the Creative Commons license, and indicate if changes were made.

\section{References}

Papers of particular interest, published recently, have been highlighted as:

-• Of major importance

1. The Diabetes Control and Complications Trial Research Group. The effect of intensive treatment of diabetes on the development and progression of long-term complications in insulin-dependent diabetes mellitus. N Engl J Med. 1993;329(14):977-86.

2. Hoey H, Aanstoot HJ, Chiarelli F, et al. Good metabolic control is associated with better quality of life in 2,101 adolescents with type 1 diabetes. Diabetes Care. 2001;24(11):1923-8.

3. DAFNE Study Group. Training in flexible, intensive insulin management to enable dietary freedom in people with type 1 diabetes: dose adjustment for normal eating (DAFNE) randomised controlled trial. BMJ. 2002;325(7367):746.

4. Lowe J, Linjawi S, Mensch M, et al. Flexible eating and flexible insulin dosing in patients with diabetes: results of an intensive selfmanagement course. Diabetes Res Clin Pract. 2008;80(3):439-43.

5. Laurenzi A, Bolla AM, Panigoni G, et al. Effects of carbohydrate counting on glucose control and quality of life over 24 weeks in adult patients with type 1 diabetes on continuous subcutaneous insulin infusion: a randomized, prospective clinical trial (GIOCAR). Diabetes Care. 2011;34(4):823-7.

6. McIntyre HD, Knight BA, Harvey DM, et al. Dose adjustment for normal eating (DAFNE) - an audit of outcomes in Australia. Med J Aust. 2010;192(11):637-40.

7. Samann A, Muhlhauser I, Bender R, et al. Glycaemic control and severe hypoglycaemia following training in flexible, intensive insulin therapy to enable dietary freedom in people with type 1 diabetes: a prospective implementation study. Diabetologia. 2005;48(10):1965-70.

8. Scavone G, Manto A, Pitocco D, et al. Effect of carbohydrate counting and medical nutritional therapy on glycaemic control in type 1 diabetic subjects: a pilot study. Diabet Med. 2010;27(4):477-9.

9. Choleau $\mathrm{C}$, Aubert $\mathrm{C}, \mathrm{Cahane} \mathrm{M}$, et al. High day-to-day glucose variability: a frequent phenomenon in children and adolescents with type 1 diabetes attending summer camp. Diabetes Metab. 2008;34(1):46-51.

10. Cameron FJ, de Beaufort C, Aanstoot HJ, et al. Lessons from the Hvidoere International Study Group on childhood diabetes: be dogmatic about outcome and flexible in approach. Pediatr Diabetes. 2013;14(7):473-80.

11. Mortensen HB, Robertson KJ, Aanstoot HJ, et al. Insulin management and metabolic control of type 1 diabetes mellitus in childhood and adolescence in 18 countries. Hvidore Study Group on childhood diabetes. Diabet Med. 1998;15(9):752-9.

12. Bell KJ, Barclay AW, Petocz P, et al. Efficacy of carbohydrate counting in type 1 diabetes: a systematic review and meta-analysis. Lancet Diabetes Endocrinol. 2014;2(2):133-40.

13. Borg R, Kuenen JC, Carstensen B, et al. Associations between features of glucose exposure and $\mathrm{A} 1 \mathrm{C}$ : the A1C-derived average glucose (ADAG) study. Diabetes. 2010;59(7):1585-90.

14. Borg R, Kuenen JC, Carstensen B, et al. $\mathrm{HbA}(1)(\mathrm{c})$ and mean blood glucose show stronger associations with cardiovascular disease risk factors than do postprandial glycaemia or glucose variability in persons with diabetes: the A1C-derived average glucose (ADAG) study. Diabetologia. 2011;54(1):69-72.

15. Smart C. Counting fat and protein: a dietitian's perspective. Diabetes Care Child Young People. 2013;2(2):71-3.

16. Pankowska E, Blazik M, Groele L. Does the fat-protein meal increase postprandial glucose level in type 1 diabetes patients on insulin pump: the conclusion of a randomized study. Diabetes Technol Ther. 2012;14(1):16-22.

17. Peters AL, Davidson MB. Protein and fat effects on glucose responses and insulin requirements in subjects with insulindependent diabetes mellitus. Am J Clin Nutr. 1993;58(4):555-60.

18.• Smart CE, Evans M, O'Connell SM, et al. Both dietary protein and fat increase postprandial glucose excursions in children with type 1 diabetes, and the effect is additive. Diabetes Care. 2013;36(12):3897-902. This study suggests that the insulin requirements of $\mathrm{CHO}$, fat and protein could be calculated independently and be added together.

19.• Wolpert HA, Atakov-Castillo A, Smith SA, et al. Dietary fat acutely increases glucose concentrations and insulin requirements in patients with type 1 diabetes: implications for carbohydrate-based bolus dose calculation and intensive diabetes management. Diabetes Care. 2013;36(4):810-6. This research attempts to quantify the impact of fat on insulin requirements and gives the potential to develop recommendations for insulin strategies.

20.• Kordonouri O, Hartmann R, Remus K, et al. Benefit of supplementary fat plus protein counting as compared with conventional carbohydrate counting for insulin bolus calculation in children with pump therapy. Pediatr Diabetes. 2012;13(7):540-4. This study confirmed that additional insulin for fat and protein improved glycaemic control but highlighted a high rate of hypoglycaemia suggesting refinement is required.

21. Slama G, Klein J, Delage A, et al. Correlation between the nature and amount of carbohydrate in meal intake and insulin delivery by the artificial pancreas in 24 insulin-dependent diabetics. Diabetes. 1981;30:101-5.

22. Service FJ, Rizza RA, Hall L, et al. Prandial insulin requirements in insulin-dependent diabetics: effects of size, time of day and sequence of meals. J Clin Endocrinol Metab. 1983;57:931-6.

23. Halfon P, Belkhadir J, Slama G. Correlation between amount of carbohydrate in mixed meals and insulin delivery by artificial pancreas in seven IDDM subjects. Diabetes Care. 1989;12:427-9. 
24. Vlachokosta FV, Piper CM, Gleason R, et al. Dietary carbohydrate, a Big Mac, and insulin requirements in type I diabetes. Diabetes Care. 1988;11(4):330-6.

25. Schrezenmeir J, Tato F, Tato S, et al. Comparison of glycemic response and insulin requirements after mixed meals of equal carbohydrate content in healthy, type-1, and type- 2 diabetic man. Klin Wochenschr. 1989;67(19):985-94.

26. Evert AB, Boucher JL, Cypress M, et al. Nutrition therapy recommendations for the management of adults with diabetes. Diabetes Care. 2014;37 Suppl 1:S120-43.

27. Smart CE, Annan F, Bruno LP, et al. Nutritional management in children and adolescents with diabetes. Pediatr Diabetes. 2014;15 Suppl 20:135-53.

28. Freckmann G, Hagenlocher S, Baumstark A, et al. Continuous glucose profiles in healthy subjects under everyday life conditions and after different meals. J Diabetes Sci Technol. 2007;1(5):695-703.

29. Desjardins K, Brazeau AS, Strychar I, et al. Association between post-dinner dietary intakes and nocturnal hypoglycemic risk in adult patients with type 1 diabetes. Diabetes Res Clin Pract. 2014;106(3):420-7.

30. Berg JM, Tymoczko J, Stryer L. Biochemistry. 7th ed. Basinstoke: W. H. Freeman; 2012.

31. Turner N, Cooney GJ, Kraegen EW, et al. Fatty acid metabolism, energy expenditure and insulin resistance in muscle. J Endocrinol. 2014;220(2):T61-79.

32. Grygiel-Gorniak B. Peroxisome proliferator-activated receptors and their ligands: nutritional and clinical implications - a review. Nutr J. 2014;13:17.

33. Radulescu A, Gannon MC, Nuttall FQ. The effect on glucagon, glucagon-like peptide-1, total and acyl-ghrelin of dietary fats ingested with and without potato. J Clin Endocrinol Metab. 2010;95(7):3385-91.

34. Lodefalk M, Carlsson-Skwirut C, Holst JJ, et al. Effects of fat supplementation on postprandial GIP, GLP-1, ghrelin and IGFBP-1 levels: a pilot study on adolescents with type 1 diabetes. Horm Res Paediatr. 2010;73(5):355-62.

35. Karhunen LJ, Juvonen KR, Huotari A, et al. Effect of protein, fat, carbohydrate and fibre on gastrointestinal peptide release in humans. Regul Pept. 2008;149(1-3):70-8.

36. Ferraris RP, Diamond J. Regulation of intestinal sugar transport. Physiol Rev. 1997;77(1):257-302.

37. Horowitz M, Edelbroek MA, Wishart JM, et al. Relationship between oral glucose tolerance and gastric emptying in normal healthy subjects. Diabetologia. 1993;36(9):857-62.

38. Carbonnel F, Lemann M, Rambaud JC, et al. Effect of the energy density of a solid-liquid meal on gastric emptying and satiety. Am J Clin Nutr. 1994;60(3):307-11.

39. Welch IM, Bruce C, Hill SE, et al. Duodenal and ileal lipid suppresses postprandial blood glucose and insulin responses in man: possible implications for the dietary management of diabetes mellitus. Clin Sci (Lond). 1987;72(2):209-16.

40. Clegg M, Pratt M, Markey O, et al. Addition of different fats to a carbohydrate food: Impact on gastric emptying, glycaemic and satiety responses and comparison with in vitro digestion. Food Res Int. 2012;48(1):91-7.

41. Clegg M, Shafat A. Energy and macronutrient composition of breakfast affect gastric emptying of lunch and subsequent food intake, satiety and satiation. Appetite. 2010;54(3):517-23.

42. Clegg M, Shafat A. Conference on "Multidisciplinary Approaches to Nutritional Problems". Postgraduate Symposium. The role of fat in gastric emptying and satiety: acute and chronic effects. Proc Nutr Soc. 2009;68(1):89-97.

43. Khan MA, Gannon MC, Nuttall FQ. Glucose appearance rate following protein ingestion in normal subjects. J Am Coll Nutr. 1992;11(6):701-6.
44. van Loon LJ, Saris WH, Verhagen H, et al. Plasma insulin responses after ingestion of different amino acid or protein mixtures with carbohydrate. Am J Clin Nutr. 2000;72(1):96-105.

45. Winiger G, Keller U, Laager R, et al. Protein content of the evening meal and nocturnal plasma glucose regulation in type-I diabetic subjects. Horm Res. 1995;44(3):101-4.

46. Krezowski PA, Nuttall FQ, Gannon MC, et al. The effect of protein ingestion on the metabolic response to oral glucose in normal individuals. Am J Clin Nutr. 1986;44(6):847-56.

47. Nordt TK, Besenthal I, Eggstein M, et al. Influence of breakfasts with different nutrient contents on glucose, $\mathrm{C}$ peptide, insulin, glucagon, triglycerides, and GIP in non-insulin-dependent diabetics. Am J Clin Nutr. 1991;53(1):155-60.

48. Garcia-Lopez JM, Gonzalez-Rodriguez M, Pazos-Couselo M, et al. Should the amounts of fat and protein be taken into consideration to calculate the lunch prandial insulin bolus? Results from a randomized crossover trial. Diabetes Technol Ther. 2013;15(2):166-71.

49. Paterson MA, Smart CE, McElduff P, et al. Influence of pure protein on postprandial blood glucose levels in individuals with type 1 diabetes mellitus (abstract). Diabetes. 2014;63(S1):A15.

50. Wilson D, Chase HP, Kollman C, et al. Low-fat vs. high-fat bedtime snacks in children and adolescents with type 1 diabetes. Pediatr Diabetes. 2008;9(4 Pt 1):320-5.

51. Brown RJ, Sinaii N, Rother KI. Too much glucagon, too little insulin: time course of pancreatic islet dysfunction in new-onset type 1 diabetes. Diabetes Care. 2008;31(7):1403-4.

52. Slag MF, Ahmad M, Gannon MC, et al. Meal stimulation of cortisol secretion: a protein induced effect. Metabolism. 1981;30(11):1104-8.

53. van Vught AJ, Nieuwenhuizen AG, Brummer RJ, et al. Somatotropic responses to soy protein alone and as part of a meal. Eur J Endocrinol. 2008;159(1):15-8.

54. Koliaki C, Kokkinos A, Tentolouris $\mathrm{N}$ et al. The effect of ingested macronutrients on postprandial ghrelin response: a critical review of existing literature data. Int J Pept. 2010;2010.

55. Wikipedia. Glucogenic amino acid. http://en.wikipedia.org/wiki/ Glucogenic amino acid. 2015. Accessed 15/03/2015.

56. Felig P, Wahren J, Sherwin R, et al. Amino acid and protein metabolism in diabetes mellitus. Arch Intern Med. 1977;137(4):507-13.

57. Linn T, Geyer R, Prassek S, et al. Effect of dietary protein intake on insulin secretion and glucose metabolism in insulin-dependent diabetes mellitus. J Clin Endocrinol Metab. 1996;81(11):3938-43.

58. Wahren J, Felig P, Hagenfeldt L. Effect of protein ingestion on splanchnic and leg metabolism in normal man and in patients with diabetes mellitus. J Clin Invest. 1976;57(4):987-99.

59. Pankowska E, Blazik M. Bolus calculator with nutrition database software, a new concept of prandial insulin programming for pump users. J Diabetes Sci Technol. 2010;4(3):571-6.

60. Neu A, Behret F, Braun R et al. Higher glucose concentrations following protein- and fat-rich meals - the Tuebingen Grill Study: a pilot study in adolescents with type 1 diabetes. Pediatr Diabetes. 2014.

61. Ryan RL, King BR, Anderson DG, et al. Influence of and optimal insulin therapy for a low-glycemic index meal in children with type 1 diabetes receiving intensive insulin therapy. Diabetes Care. 2008;31(8):1485-90.

62. Scaramuzza AE, Iafusco D, Santoro L, et al. Timing of bolus in children with type 1 diabetes using continuous subcutaneous insulin infusion (TiBoDi Study). Diabetes Technol Ther. 2010;12(2):14952.

63. Jovanovic L, Giammattei J, Acquistapace M, et al. Efficacy comparison between preprandial and postprandial insulin aspart administration with dose adjustment for unpredictable meal size. Clin Ther. 2004;26(9):1492-7.

64. Cobry E, McFann K, Messer L, et al. Timing of meal insulin boluses to achieve optimal postprandial glycemic control in patients with type 1 diabetes. Diabetes Technol Ther. 2010;12(3):173-7. 
65. Chase HP, Saib SZ, MacKenzie T, et al. Post-prandial glucose excursions following four methods of bolus insulin administration in subjects with type 1 diabetes. Diabet Med. 2002;19(4):317-21.

66. Lopez P, Smart C, Morbey C, et al. Extended insulin boluses cannot control postprandial glycemia as well as a standard bolus in children and adults using insulin pump therapy. BMJ Open Diabetes Res Care. 2014;2(1), e000050.

67. Bao J, Gilbertson HR, Gray R, et al. Improving the estimation of mealtime insulin dose in adults with type 1 diabetes: the Normal Insulin Demand for Dose Adjustment (NIDDA) study. Diabetes Care. 2011;34(10):2146-51.

68. Bell KJ, Gray R, Munns D, et al. Estimating insulin demand for protein-containing foods using the food insulin index. Eur J Clin Nutr. 2014;68(9):1055-9.
69. Bell K, Toschi, E, Wolpert, H, Steil, G. Use of model predicted bolus estimation (mpb) to optimize insulin dosing strategies covering high fat meals. 8th International Conference on Advanced Technologies and Treatments for Diabetes; Paris, France 2015.

70. Lindholm-Olinder ARJ, Smide B, Kernell A. Post-prandial glucose levels following three methods of insulin bolusing: a study in adolescent girls and in comparison with girls without diabetes. Pract Diabetes Int. 2009;26(3):110-5.

71. Jones SM, Quarry JL, Caldwell-McMillan M, et al. Optimal insulin pump dosing and postprandial glycemia following a pizza meal using the continuous glucose monitoring system. Diabetes Technol Ther. 2005;7(2):233-40. 